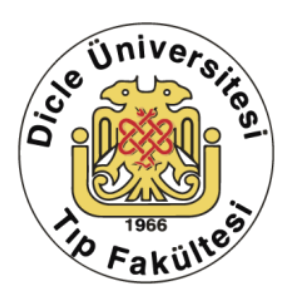

\title{
The effect of Hashimoto's thyroiditis on platelets in terms of the their number, size, and distribution
}

\author{
Bulent Guvendi , Fatih Kara², Gulname Findik Guvendi³, Yasemen Adali ${ }^{4}$, Tugba Toyran $^{5}$, \\ Kenan Binnetoglu ${ }^{6}$, Mahmut Can Yagmurdur ${ }^{7}$
}

1 Kafkas University, Faculty of Medicine, Department of General Surgery, Kars, Turkey ORCID: 0000-0002-0930-0443

2 Kafkas University, Faculty of Medicine, Department of Biochemistry, Kars, Turkey ORCID: 0000-0002-9729-5380

3 Recep Tayyip Erdoğan University, Faculty of Medicine, Department of Pathology, Rize, Turkey ORCID: 0000-0001-9370-4880

4 Canakkale Onsekiz Mart University, Faculty of Medicine, Department of Pathology, Canakkale, Turkey ORCID: 0000-0002-8004-7364

5 Cukurova University, Faculty of Medicine, Department of Pathology, Adana, Turkey ORCID: 0000-0001-9135-0265

6 Kafkas University, Faculty of Medicine, Department of General Surgery, Kars, Turkey ORCID: 0000-0001-7517-5970

7 Private Clinic, General Surgery, Ankara, Turkey ORCID: 0000-0003-3559-0496

Received: 06.05.2018; Revised: 20.03.2019; Accepted: 03.05.2019

\begin{abstract}
Objective: The aim of our study was to investigate whether platelet indices were affected in patients with Hashimoto's thyroiditis (HT).

Method: 11 patients (10 female, 1 male) with HT and 26 subjects with nodular goiters ( 19 female, 7 male) selected as control group were included in the study. All cases were examined for complete blood count parameters (leukocyte count, neutrophil count and percentage, lymphocyte count and percentage, platelet count, plateletcrit, platelet distribution width (PDW), and mean platelet volume (MPV)).

Results: Leukocyte count, neutrophil count and percentage, lymphocyte percentage, platelet count, plateletcrit, and MPV in the patient group were not statistically different from the control group. Lymphocyte count and PDW were significantly higher in patients with HT than in the control group.

Conclusion: Our results suggest that patients with HT have higher PDW levels. Increased PDW in HT may be helpful in diagnosis, floow-up, and prognosis of the disease.
\end{abstract}

Keywords: Thyroid, Hashimoto, platelet.

\section{DOI: $10.5798 /$ dicletip}




\section{Hashimoto tiroiditinin trombositler üzerine sayı, büyüklük ve dağılım açısından etkisi}

\section{Öz}

Amaç: Çalışmamızın amacı, Hashimoto tiroiditi olan hastalarda trombosit endekslerinin etkilenip etkilenmediğini araștırmaktır.

Yöntemler: HT'li 11 hasta (10 kadın, 1 erkek) ve kontrol grubu olarak seçilen nodüler guatrlı 26 kişi (19 kadın, 7 erkek) çalışmaya dahil edildi. Tüm olguların tam kan sayımı parametreleri (lökosit sayısı, nötrofil sayısı ve yüzdesi, lenfosit sayısı ve yüzdesi, trombosit sayısı, trombosit yüzdesi, trombosit dağılım genişliği (PDW) ve ortalama trombosit hacmi (MPV)) incelendi.

Bulgular: Hasta grubunda lökosit sayısı, nötrofil sayısı ve yüzdesi, lenfosit yüzdesi, trombosit sayısı, platelet yüzdesi ve MPV değerleri kontrol grubundan istatistiksel olarak farklı değildi. Lenfosit sayısı ve PDW, HT'li hastalarda kontrol grubuna göre anlamlı derecede yüksekti.

Sonuç: Bulgularımız HT'li hastaların PDW düzeylerinin daha yüksek olduğunu göstermektedir. HT'de artmış PDW, hastalığın tanısı, takibi ve prognozu açısından anlamlı olabilir.

Anahtar kelimeler: Tiroid, hashimoto, trombosit.

\section{INTRODUCTION}

Hashimoto's thyroiditis (HT), part of the spectrum of autoimmune thyroid diseases, is the most common form of inflammatory thyroid disorders and the most common cause of hypothyroidism ${ }^{1,2}$. An increase in the incidence of HT has attracted attention in recent years ${ }^{3}$. It is known that a number of genetic and environmental factors are responsible for the development of HT, while there are still many unexplained points in the etiopathogenesis 4 . Many studies showed that both cellular and humoral immunity are important in $\mathrm{HT}^{5,6}$. Activation of follicular helper $\mathrm{T}$ cells and disturbance of $\mathrm{T}$ regulatory cells may play a role in initiation/perpetuation of the disease ${ }^{3}$. There is a growing interest about the effects of platelets on immunological and inflammatory processes ${ }^{7-10}$. There is a limited number of studies in the literature on the relationship between HT and platelet indices ${ }^{11-13}$. Inflammatory condition in HT can affect the number, the size, and the distribution of blood platelets ${ }^{7,11-13}$. The aim of our study was to investigate whether platelet indices were affected in patients with pathologically diagnosed HT.

\section{METHODS}

This study started with the approval of the Ethics Committee of the Faculty of Medicine of our University (31.05.2017/101). Between 01.03.2014 and 28.02.2017, 11 patients (10 female, 1 male) with HT diagnosis in the pathology clinic of our University Research and Practice Center Hospital and 26 cases of nodular goiters (19 female, 7 male) selected as control group were included in the study. The aim of that we selected the patients with nodular goiter as control group was to ensure that they didn't have pathologically HT. Exclusion criteria were as follows: a chronic disease such as asthma, chronic obstructive pulmonary disease, and hypertension and/or concomitant thyroid carcinoma.

All patients who were included in the study were examined for complete blood count parameters (leukocyte count, neutrophil count and percentage, lymphocyte count and percentage, platelet count, plateletcrit, platelet distribution width (PDW), and mean platelet volume (MPV)). These parameters were measured by a hematology analyzer (ABX Pentra DX 120, HORIBA, France). 


\section{Statistical Analyses}

The Kolmogorov-Smirnov test was used to determine whether the variables were distributed normally. Fisher's exact test was used to determine whether there is a gender difference between the groups and MannWhitney $\mathrm{U}$ test to determine whether there is a difference in terms of age, leukocyte count, neutrophil count and percentage, lymphocyte count and percentage, platelet count, plateletcrit, PDW, and MPV. A p value less than 0.05 was considered statistically significant.

\section{RESULTS}

There was no significant difference between the groups in terms of age and gender (Table 1). Leukocyte count, neutrophil count and percentage, lymphocyte percentage, platelet count, plateletcrit, and MPV in the patient group were not statistically different from the control group (Table 1). Lymphocyte count and PDW were significantly higher in patients with HT than in the control group (Figures 1, 2, and $3)$.

\section{DISCUSSION}

HT is an autoimmune disease characterized by the infiltration of the thyroid gland by both $B$ and $\mathrm{T}$ lymphocytes. For this reason, there is a role for both cellular and humoral immunity in its pathogenesis ${ }^{3}$. We found that lymphocytes count in peripheral blood of patients with HT was significantly higher than in the control group (Figure 1). Lymphocytosis is a nonspecific finding that is common during the healing period of many acute infectious diseases. It is known that HT is one of noninfectious diseases associated with lymphocytosis ${ }^{14}$.
Table 1: Comparison of age, gender distribution, and complete blood count parameters between control group (nodular goiter) and patients with Hashimoto's thyroiditis.

\begin{tabular}{|c|c|c|c|}
\hline & $\begin{array}{c}\text { Hashimoto's } \\
\text { thyroiditis } \\
(n=11)\end{array}$ & $\begin{array}{l}\text { Nodular } \\
\text { goiter } \\
(n=26)\end{array}$ & $\mathrm{p}$ \\
\hline Age & $41.0 \pm 14.1$ & $46.4 \pm 14.2$ & 0.421 \\
\hline \multirow{2}{*}{ Gender } & 10 & 19 & \multirow{2}{*}{0.391} \\
\hline & 1 & 7 & \\
\hline Leukocyte count $\left(\mathrm{x} 10^{3} / \mathrm{mm}^{3}\right)$ & $7.34 \pm 2.13$ & $7.00 \pm 1.78$ & 0.544 \\
\hline Neutrophil count $\left(\mathrm{x} 10^{3} / \mathrm{mm}^{3}\right)$ & $4.61 \pm 2.08$ & $4.65 \pm 1.63$ & 0.857 \\
\hline Neutrophil percentage (\%) & $60.3 \pm 11.5$ & $65.5 \pm 8.5$ & 0.181 \\
\hline Lymphocyte count $\left(\mathrm{x} 10^{3} / \mathrm{mm}^{3}\right)$ & $2.37 \pm 0.87$ & $1.77 \pm 0.67$ & 0.023 \\
\hline Lymphocyte percentage (\%) & $30.1 \pm 10.1$ & $26.2 \pm 7.8$ & 0.270 \\
\hline Platelet count $\left(\mathrm{x} 10^{3} / \mathrm{mm}^{3}\right)$ & $288.2 \pm 61.7$ & $288.6 \pm 92.6$ & 1.000 \\
\hline Plateletcrit (\%) & $0.276 \pm 0.051$ & $0.275 \pm 0.114$ & 0.402 \\
\hline Platelet distribution width (\%) & $14.8 \pm 1.9$ & $12.6 \pm 2.2$ & 0.005 \\
\hline Mean platelet volume (fL) & $9.8 \pm 1.8$ & $9.6 \pm 1.7$ & 0.682 \\
\hline
\end{tabular}

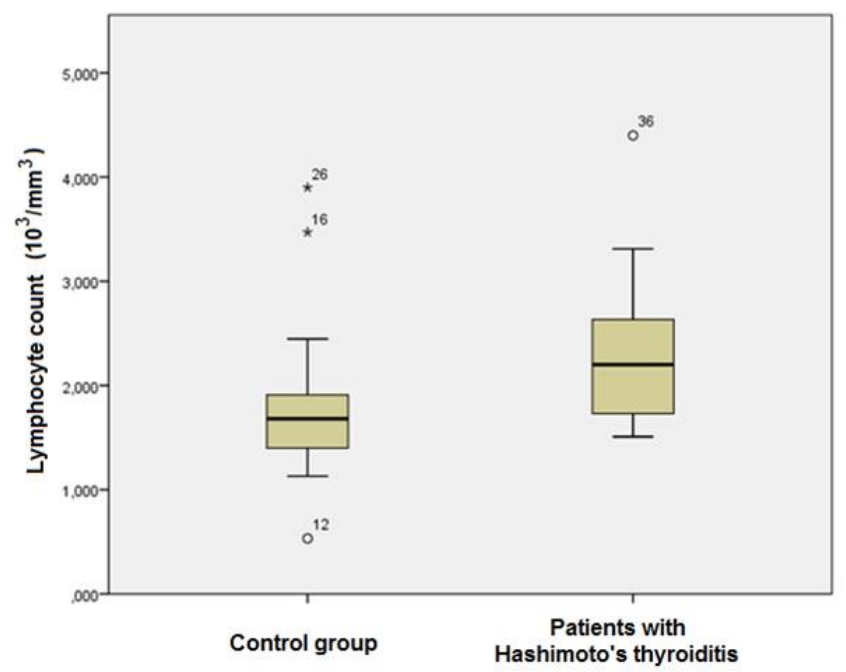

Figure 1. Comparison of lymphocyte count between control group and patients with Hashimoto's thyroiditis. 


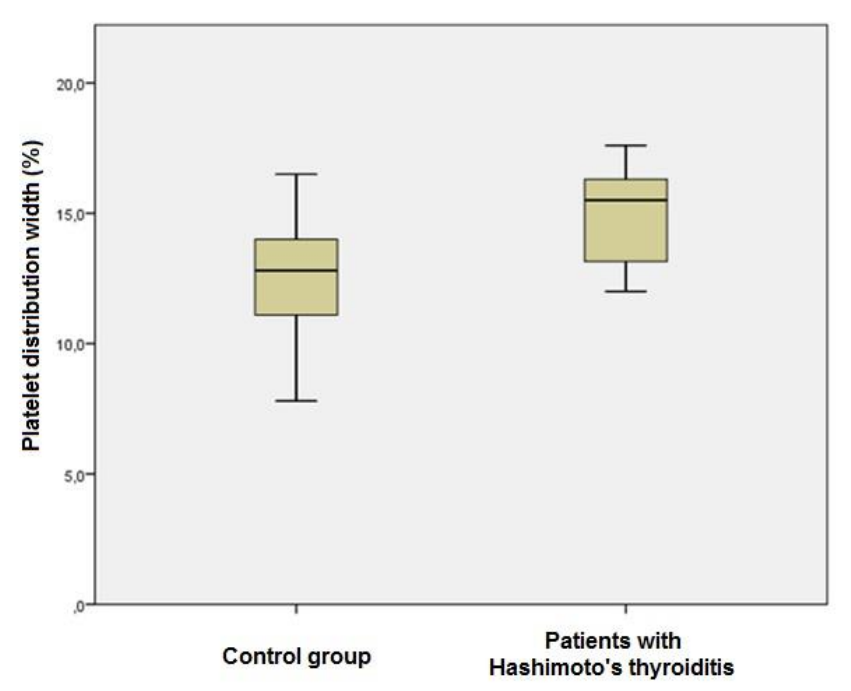

Figure 2. Comparison of platelet distribution width between control group and patients with Hashimoto's thyroiditis.

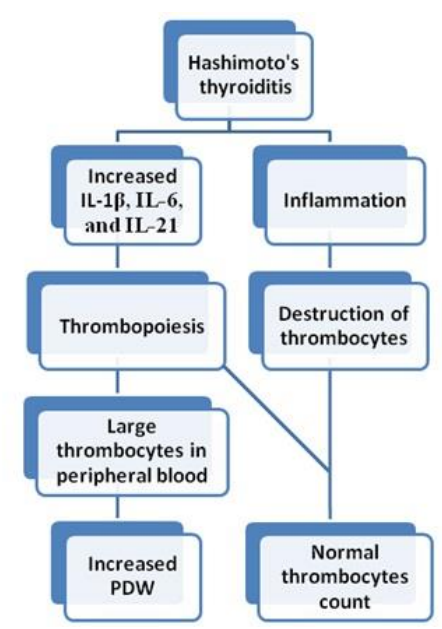

Figure 3. Percentage change of complete blood count parameters in patients with Hashimoto's thyroiditis compared to that of control group. The bars in the graph have be ordered from left to right as follows: leukocyte count, neutrophil count, neutrophil percentage, lymphocyte count, lymphocyte percentage, platelet count, plateletcrit, platelet distribution width, mean platelet volume.

Our study showed that the PDW values, a specific marker of platelet activation, were significantly increased in HT. Sit et all. ${ }^{11}$ and Aktas et all. ${ }^{15}$ found that PDW values in patients with HT did not differ from those in healthy controls. Atile et all. ${ }^{16}$ raported that PDW values of patients with hypothyroid HT were similar to those of both healthy controls and patients with treated euthyroid HT. However,
Bilge et all. ${ }^{17}$ found that PDW values were significantly increased in euthyroid women with HT compared with healthy controls. The findings of our study agree with those of Bilge et all. Zhu et all. ${ }^{18}$ have determined elevated follicular helper $\mathrm{T}$ cells in the peripheral blood of patients with HT. It has been shown that follicular helper $\mathrm{T}$ cells produce high levels of IL-21 that is associated with the development of autoimmune diseases ${ }^{19,20}$. Cytokines such as IL-1 $\beta$, IL-6, and IL-21 can play a role in the pathogenesis of $\mathrm{HT}^{20-22}$ and also can enhance thrombopoiesis ${ }^{24}$. Accelerated thrombocytes generation leads to presence of large thrombocytes ${ }^{25}$, hence, to increased PDW.

We found that platelet count was not different in patients with HT compared with that of control group. This result agreed with previous studies ${ }^{11,12}$. During inflammatory process, there is a rapid recruitment of thrombocytes to the field of inflammation where they are consumed due to their destruction ${ }^{26}$. For this reason we consider that in patients with HT, platelet production increases, but, on the other hand, platelet consumption also enhances and thus platelet count remains unchanged (Figure 4).

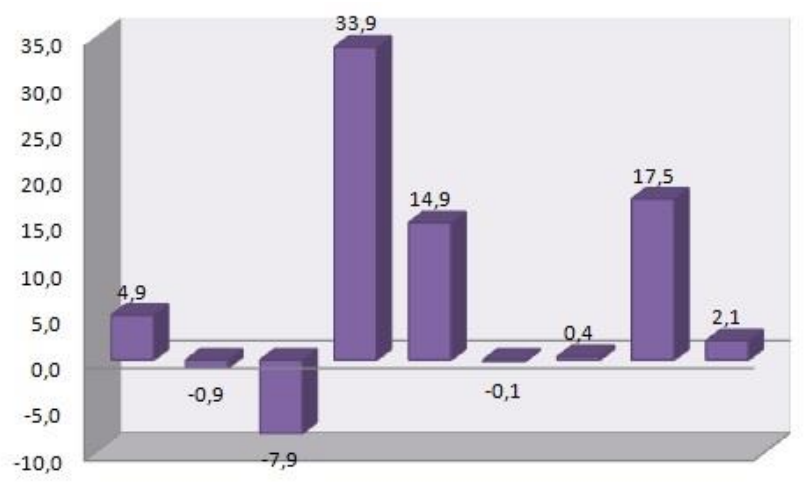

Figure 4. Possible molecular mechanism of the increase in platelet distribution width in Hashimoto's thyroiditis. 
In conclusion, our results suggest that patients with HT have higher PDW levels. Increased PDW in HT may be helpful in diagnosis, followup, and prognosis of the disease and for better understanding of mechanisms associated with the disease pathogenesis. However, further studies are need to confirm its validity in patients with HT.

Conflicts of interest: The authors have no conflict of interests to declare.

Financial Disclosure: The authors declared that this study has received no financial support.

\section{REFERENCES}

1. Lal G, Clark OH. Textbook of endocrine surgery. Philadelphia: Saunders; 2005.p.38-40.

2. Kumar V, Robbins SL. Robbins basic pathology. Philadelphia, PA: Saunders/Elsevier; 2007:p.731-6.

3. Ajjan RA, Weetman AP. The pathogenesis of Hashimoto's thyroiditis: further developments in our understanding. Horm Metab Res 2015; 47: 702-10.

4. Effraimidis G, Wiersinga WM. Mechanisms in endocrinology: autoimmune thyroid disease: old and new players. Eur J Endocrinol 2014; 170: R241-52.

5. Weetman AP. Cellular immune responses in autoimmune thyroid disease. Clin Endocrinol (Oxf) 2004; 61: 405-13.

6. Volpe R. Suppressor T lymphocyte dysfunction is important in the pathogenesis of autoimmune thyroid disease: a perspective. Thyroid 1993; 3: 345-52.

7. Thomas MR, Storey RF. The role of platelets in inflammation. Thromb Haemost 2015; 114: 449-58.

8. Islamoğlu Y, Buyukkaya E, Kaya Z, et all. Effect of the hematological and biochemical parameters on outcomes of the patients with infective endocarditis. Dicle Med J. 2011; 38: 392-7.

9. Kilic E, Rezvani A, Toprak AE, et all. Evaluation of Neutrophil to Lymphocyte and Platelet to Lymphocyte Ratios in Rheumatoid Arthritis. Dicle Med J. 2016; 43: 241-7.

10. Guvendi B, Kara F, Binnetoglu K, et all. Comparison of platelet indices in papillary thyroid carcinoma and microcarcinoma. J Turgut Ozal Med Cent. 2018; 25: 122-4.

11. Sit M, Kargi E, Aktas G, et all. Mean platelet volume should be a useful indicator in diagnosis of Hashimoto's thyroiditis. Acta Medica Mediterranea 2014; 30: 1263 6.
12. Carlioglu A, Timur O, Durmaz SA, Ayhan ME. Mean platelet volume in euthyroid patients with Hashimoto's thyroiditis. Blood Coagul Fibrinolysis 2015; 26: 282-4.

13. Savas E, Sahin AZ, Aksoy SN, et all. Serum levels of inflammatory markers in patients with thyroid dysfunction and their association with autoimmunity status. Int J Clin Exp Med 2016; 9: 4485-90.

14. Gorbach SL, Bartlett JG, Blacklow NR. Infectious diseases. Philadelphia: Lippincott Williams \& Wilkins; 2004: 159.

15. Aktas G, Sit M, Dikbas O, et all. Could red cell distribution width be a marker in Hashimoto's thyroiditis? Experimental and Clinical Endocrinology \& Diabetes. 2014; 122: 572-4.

16. Atile NS, Bilir BE, Bilir B, Guldiken S. Mean platelet volume levels in patients with overt hypothyroidism before and after levothyroxine treatment. Acta Endocrinologica (Buc), 2012; 8: 607-14.

17. Bilge M, Adas M, Yesilova A, Helvaci A. Mean platelet volume (MPV) and platelet distribution width (PDW) in euthyroid woman with Hashimoto's Thyroiditis. Endocrine Abstracts 2016; 41: EP968.

18. Zhu C, Ma J, Liu Y, et all. Increased frequency of follicular helper $\mathrm{T}$ cells in patients with autoimmune thyroid disease. J Clin Endocrinol Metab 2012; 97: 94350.

19. Spolski R, Leonard WJ. IL-21 and T follicular helper cells. Int Immunol 2010; 22: 7-12.

20. El-Shenawy SZ, Hemi MH, Attia H. Serum levels of proinflammatory cytokines (interleukin 6 \& interleukin 15) and adiponectin in Hashimoto's thyroiditis with different thyroid function states. Journal of American Science 2011; 7: 1156-62.

21. Rebuffat SA, Kammoun-Krichen M, Charfeddine I, et all. IL-1 $\beta$ and TSH disturb thyroid epithelium integrity in autoimmune thyroid diseases. Immunobiology 2013; 218: 285-91.

22. Guan LJ, Wang X, Meng S, et all. Increased IL-21/IL$21 \mathrm{R}$ expression and its proinflammatory effects in autoimmune thyroid disease. Cytokine 2015; 72: 160-5.

23. Benbarche S, Strassel C, Angenieux C, et all. Dual role of IL-21 in megakaryopoiesis and platelet homeostasis. Haematologica 2017; 102: 637-46.

24. Cortin V, Garnier A, Pineault N, et all. Efficient in vitro megakaryocyte maturation using cytokine cocktails optimized by statistical experimental design. Exp Hematol. 2005; 33: 1182-91.

25. Fox JG, Barthold S, Davisson M, et all. The mouse in biomedical research: normative biology, husbandry, and models. Amsterdam: Academic Press, 2006: 156.

26. Danese S, Motte Cd Cde L, Fiocchi C. Platelets in inflammatory bowel disease: clinical, pathogenic, and therapeutic implications. Am J Gastroenterol. 2004; 99: 938-45. 